\title{
Binding properties of rat prorenin and renin to the recombinant rat renin/prorenin receptor prepared by a baculovirus expression system
}

\author{
A.H.M. NURUN NABI ${ }^{1}$, AYANO KAGESHIMA ${ }^{3}$, MOHAMMAD NASIR UDDIN $^{2}$, \\ TSUTOMU NAKAGAWA ${ }^{2}$, ENOCH Y. PARK ${ }^{2,3}$ and FUMIAKI SUZUKI ${ }^{1,2}$ \\ ${ }^{1}$ Graduate School of Agricultural Science and ${ }^{2}$ Faculty of Applied Biological Sciences, Gifu University, Gifu 501-1193, \\ ${ }^{3}$ Department of Applied Biological Chemistry, Faculty of Agriculture, Shizuoka University, Shizuoka 422-8529, Japan
}

Received February 16, 2006; Accepted May 17, 2006

\begin{abstract}
The rat recombinant renin/prorenin receptor (AB188298 in DDJB), which conjugated with FLAG epitope in its $\mathrm{N}$-terminus, was expressed in a baculovirus expression system. The recombinant receptor, prepared from the cytoplasmic fraction of the insect cells, was identified by Western blotting using anti-FLAG antibody. Prorenin as well as renin bound to the receptor with different binding affinities. Their $K_{\mathrm{d}}$ values were estimated at 8.0 and $20 \mathrm{nM}$, respectively. The amounts of prorenin and renin bound to the immobilized receptors were 1.0 and 0.2 pmole, respectively. The prorenin bound to the receptor had renin activity and the renin kept the activity at similar level to that before the binding. The $K_{\mathrm{m}}$ of their complexes was the same at $3.3 \mu \mathrm{M}$ when sheep angiotensinogen was used as the substrate. Their $V_{\max }$ values were 5.5 and $10 \mathrm{nM} \cdot \mathrm{h}^{-1}$, respectively. The molecular activities of prorenin and renin bound to the receptor were 1.1 and $10 \mathrm{~h}^{-1}$, respectively. From these findings, rat prorenin as well as renin was indicated to bind to the recombinant receptor and express the enzymatic activity in vitro.
\end{abstract}

\section{Introduction}

Renin-angiotensin system plays a pivotal role in maintaining the blood pressure and electrolyte balance in mammals (1). Recently, prorenin, the inactive proenzyme of renin, was studied in relation to the system. Prorenin with 43 amino acid residue in the prosegment region has reportedly been activated non-proteolytically by an acidification or under low temperature to change its conformation locally $(2,3)$. A

Correspondence to: Dr Fumiaki Suzuki, Laboratory of Animal Biochemistry, Faculty of Applied Biological Sciences, Gifu University, Yanagido 1-1, 501-1193 Gifu, Japan

E-mail: aob3073@cc.gifu-u.ac.jp

Key words: renin-angiotensin system, recombinant rat renin/ prorenin receptor, rat renin, rat prorenin, baculovirus functional renin/prorenin receptor has been found that acts as a renin/prorenin cofactor on the cell surface, enhancing the efficiency of angiotensinogen cleavage by renin and unmasking prorenin catalytic activity (4). Moreover, the nonproteolytic activation of prorenin through protein-protein interaction has been demonstrated in vitro at physiological $\mathrm{pH}$, using specific antibodies (5).

Many kinds of renin/prorenin receptors have been reported (6-8). For example, the mannose-6-phosphate receptor, which has been the most extensively studied, mediated only uptake of renin and prorenin in the cell rather than showed other functions on the cell membrane (6). On the other hand, prourokinase binding to the urokinase receptor was reported to induce a conformational change in the proform into the non-proteolytic activation (9). Certain receptor-bound mature enzymes were much more efficient in the catalytic activity $(10,11)$. We have transiently expressed the rat renin/prorenin receptor on the membrane of the COS-7 cells to study the non-proteolytic activation mechanism of the rat prorenin (12). The expressed amount on the membrane was insufficient to investigate the binding mechanism in detail. In this study, a baculovirus expression system $(13,14)$ was applied to obtain sufficient amount of recombinant rat renin/prorenin receptor.

As several strains of rats are widely used as a model animal in the studies on blood pressure regulation and hypertension, rat prorenin reports have attracted the attention of renin and prorenin investigators. However, the activation of rat prorenin took longer at acidic $\mathrm{pH}(15)$ and the rate of its acid activation was one-fifth of that of the human prorenin (16). The rat prorenin has commonly been considered inactive in blood circulation. In this study, we investigated in vitro the binding properties of rat renin and prorenin to the recombinant renin/prorenin receptor, obtained by the baculovirus expression system, to understand the binding and activation of rat renin and prorenin at a neutral $\mathrm{pH}$.

\section{Materials and methods}

Antibodies. Different types of antibodies were used in this study. Anti-rat renin antibody (a kind gift from Professor Inagami, 17) was used to detect rat mature renin. MC13 
antibody against the C-terminal region of the prosegment of prorenin was prepared in immunized rabbit. Anti-FLAG-M2 antibody, Protein A-HRP (horseradish peroxidase) conjugate and anti-mouse $\operatorname{IgG}$ antibody labeled with HRP were purchased from Sigma and Bio-Rad, USA.

Construction of the vector. The rat renin/prorenin receptor cDNA with FLAG epitope was amplified by PCR using Pst I and EcoRI restriction sites. The designed primers were as follows: forward primer: 5'-CACCATGGCTGTTGTCGT CTCCTC-3'; reverse primer: 5'-CGGAATTCTAATCCA TTCGAATCTTCTGG-3'. The PCR product was inserted into the entry vector, $\mathrm{pENTR/D-TOPO} \mathrm{(Invitrogen,} \mathrm{San} \mathrm{Diego,} \mathrm{CA,}$ USA) containing PstI and EcoRI restriction sites along with rat signal sequence and cytoplasmic region. The resulting pENTR-renin/prorenin receptor-FLAG, was inserted into a pDEST 8 donor vector by Gateway Cloning Technology (Invitrogen). The recombinant donor vector, pDEST-renin/ prorenin-FLAG was transformed into E. coli DH10, which contained a bacmid. The recombinant bacmid was extracted from E. coli and transfected Tn-5B1-4 cells from Trichoplusia ni (Invitrogen). Finally, the recombinant AcNPV-renin/ prorenin receptor cDNA harboring plasmid under the control of viral polyhedron promoter was constructed. Four million Tn-5B1-4 cells were infected at a multiplicity of infection (MOI) of 5 with a recombinant baculovirus. The cytoplasmic fraction $(12.0 \mathrm{ml})$ of the receptor was collected two days after transfection of the cells.

Western blot analysis. To detect the expression of recombinant protein, cytoplasmic fractions were subjected to SDS/PAGE (12\% polyacrylamide) (18) using the Mini-protean II system (Bio-Rad). Total protein of culture supernatants was precipitated with $2 \%(\mathrm{w} / \mathrm{v})$ trichloroacetic acid and washed with $50 \mathrm{mM}$ Tris $/ \mathrm{HCl}(\mathrm{pH} 7.5)$. Precipitated protein was dissolved with SDS/PAGE sample buffer $(9.5 \mathrm{ml})$ [3.5 $\mathrm{ml}$ of distilled water, $1.25 \mathrm{ml}$ of $0.5 \mathrm{M}$ Tris/ $\mathrm{HCl}$ (pH 6.8), $2.5 \mathrm{ml}$ of glycerol, $2 \mathrm{ml}$ of $10 \%(\mathrm{w} / \mathrm{v}) \mathrm{SDS}$ and $0.2 \mathrm{ml}$ of $0.5 \%(\mathrm{w} / \mathrm{v})$ bromophenol blue] and subjected to SDS/PAGE. Magic Mark $^{\mathrm{TM}}$ XP Western protein standards (Invitrogen) were used as standard protein for the blot and using anti-FLAG-M2 and anti-mouse IgG/HRP (horseradish peroxidase) antibodies the bands were visualized. After SDS/PAGE, the proteins were blotted onto a PVDF membrane using the Mini Trans-Blot Electrophoretic Transfer Cell (Bio-Rad). After blocking in $5 \%$ Tris-buffered saline (pH 7.6) [2.42 g (20 mM) Tris-base, $8 \mathrm{~g} \mathrm{NaCl}$ and $3.8 \mathrm{ml}(1 \mathrm{M}) \mathrm{HCl}$ ] containing $0.1 \%$ Tween-20, the membrane was incubated in 1:10,000 diluted anti-FLAGM2 solution for $1 \mathrm{~h}$. The membrane was washed and then incubated in 1:20,000 diluted anti-mouse IgG antibody labeled with HRP for $1 \mathrm{~h}$. Using ECL plus Western blotting reagent pack (Amersham Biosciences) specific bands were detected. Those bands were analyzed using a Fluor-S/MAX multi-imager (Bio-Rad).

Preparation of rat renin and prorenin. Chinese hamster ovary cell line harboring rat prorenin cDNA was maintained (19) under humidified atmosphere of $5 \% \mathrm{CO}_{2}$ and $95 \%$ air in $25-\mathrm{cm}^{2}$ cell culture flasks (Cellstar, Greiner, Bio-One Germany) until achieving $100 \%$ confluent monolayer in the (a)

(b)

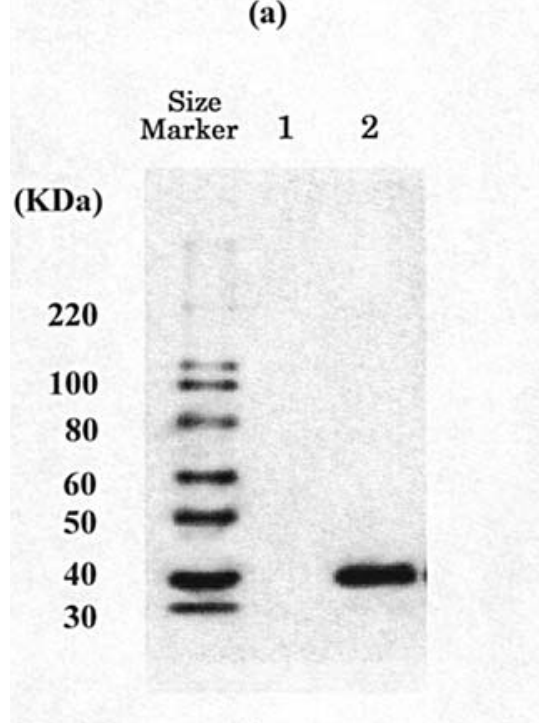

Figure 1. Western blot analysis of the cytoplasmic fraction from Tn5 cells. Protein band was detected by mouse anti-FLAG-M2 monoclonal antibody and anti-mouse IgG antibody labelled with HRP. Molecular mass of the recombinant rat renin/prorenin receptor was $40 \mathrm{kDa}$ as shown in lane 2 (a) and lane 1 was for the fraction of control cells without any transfection. Recombinant receptors immobilized in the 96-well plates were confirmed by using the anti-FLAG-M2 antibody and Protein A-HRP conjugate as shown by bar 2 (b). Cytoplasmic fraction of the cells without any transfection was used as the control shown by bar 1 (b).

Dulbecco's modified Eagle's medium (DMEM) containing $0.1 \mathrm{mM}$ non-essential amino acids, $2 \mathrm{mM}$ glutamine, $100 \mathrm{U}$ penicillin, $100 \mu \mathrm{g}$ streptomycin per $\mathrm{ml}, 200 \mathrm{nM}$ methotraxate supplemented with 5\% dialyzed FBS. Recombinant rat renin (Mr: 42,000) was prepared by the proteolytic activation of recombinant rat prorenin $(\mathrm{Mr} 46,000)$ with trypsin at $25^{\circ} \mathrm{C}$ for $40 \mathrm{~min}$ (final concentration was $2.0 \mathrm{mg} / \mathrm{ml}$ ). Immobilized Soybean Trypsin Inhibitor (agarose-bound SBTI, $4.0 \mathrm{mg} / \mathrm{ml}$ ) was added to stop the proteolytic reaction. Finally, the reaction mixture was centrifuged twice with immobilized SBTI to remove any trace of trypsin. The prorenin and renin preparations were stored at $-80^{\circ} \mathrm{C}$ until further study.

Determination of $K_{\mathrm{d}}$ for receptor binding of rat renin and prorenin. After 20 times dilution of the original receptor preparation, $200 \mu \mathrm{l}$ aliquots were allowed to immobilize in the 96 -well plate at $4^{\circ} \mathrm{C}$ for $24 \mathrm{~h}$ using blocking buffer $(0.1 \%$ casein in phospate-buffered saline). The prorenin preparation was incubated at $37^{\circ} \mathrm{C}$ for $1 \mathrm{~h}$ to avoid possible cryoactivation. By this treatment, variation in the inactive prorenin level in each experiment was minimized to $<2 \%$ of its total potential renin activity attainable by trypsin treatment. The $K_{\mathrm{d}}$ values for the binding of renin and prorenin to the receptor were calculated by determining the concentrationdependent binding to the receptor. Different concentrations of renin and prorenin (from 1 to $20 \mathrm{nM}$ ) incubated in the $200 \mu \mathrm{l}$ medium with the immobilized recombinant receptors at $4^{\circ} \mathrm{C}$ for $30 \mathrm{~min}$. After incubation, renin and prorenin media were removed. Amounts of receptor-bound renin and prorenin were estimated by subtracting remained amount of renin and prorenin from their initial concentration. 
a. Prorenin bound to receptor

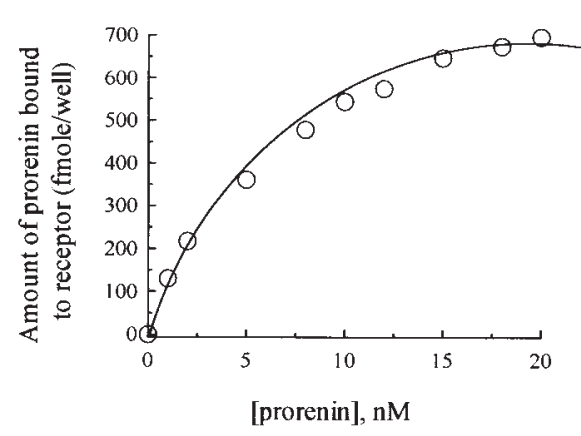

b. Renin bound to receptor

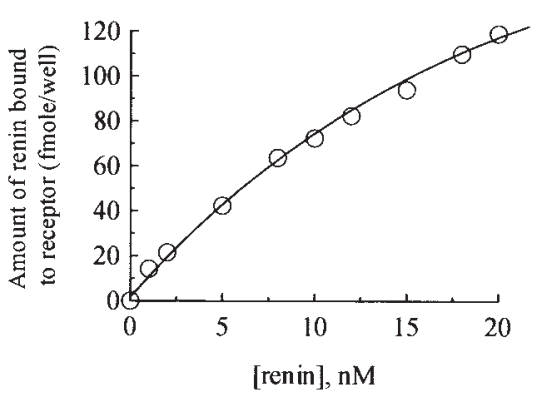

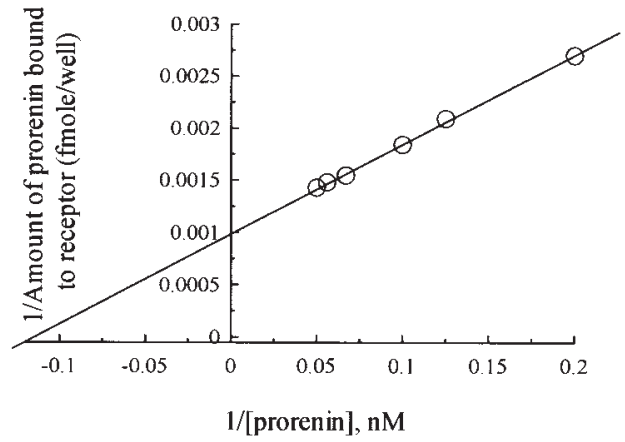

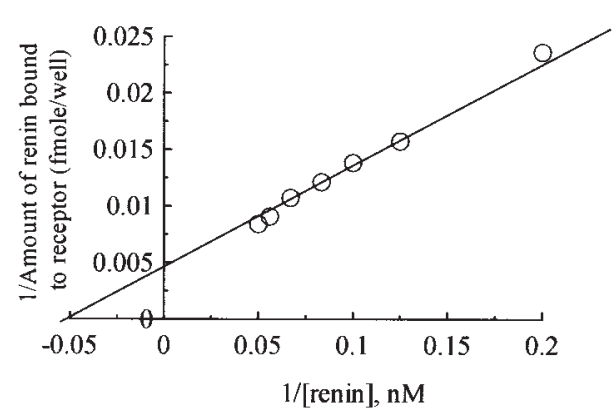

Figure 2. Binding of rat prorenin and renin to the rat renin/prorenin receptor. Different concentrations (1-20 nM) of renin and prorenin were allowed to bind with the recombinant immobilized receptor. Amounts of bound renin and prorenin ( $200 \mu 1$ of the original preparations) were determined by subtracting the remaining amount of unbound renin/prorenin from their initial amount. The double reciprocal plots, 1/amount of receptor-bound prorenin vs. 1/[prorenin] (a) and $1 /$ amount of receptor-bound renin vs. $1 /\left[\right.$ renin] (b), were used to determine the $K_{\mathrm{d}}$ and maximum binding amounts. The $K_{\mathrm{d}}$ values were estimated to be 8.3 and $20 \mathrm{nM}$, respectively. The maximum binding amounts of renin and prorenin were 0.2 and 1.0 pmole, respectively.

Determination of $K_{\mathrm{m}}$ of the receptor-bound renin and prorenin. Rat renin and prorenin preparations were incubated in $200 \mu \mathrm{l}$ of medium with the receptors coated in the 96-well plate at $4^{\circ} \mathrm{C}$ for $30 \mathrm{~min}$ and then removed. The wells were washed with ice-cold PBS. The $K_{\mathrm{m}}$ values were determined from the rate of Ang I production at sheep angiotensinogen concentrations of 0.3-2.8 $\mu \mathrm{M}$. Enzymatic activities of receptor-bound renin and prorenin were measured by angiotensin I ELISA (20) after incubation of receptor-bound renin and prorenin with the recombinant sheep angiotensinogen preparation (21) under standard assay conditions as described previously (22).

Estimation of the molecular activity of the bound form of renin and prorenin. Different concentrations of renin and prorenin (from 1 to $20 \mathrm{nM}$ ) were incubated in the $200 \mu 1$ medium with the recombinant receptors immobilized in the 96-well plate at $4^{\circ} \mathrm{C}$ for $30 \mathrm{~min}$. After incubation, amounts of receptor-bound renin and prorenin were estimated by subtracting the remaining amount of renin and prorenin from their initial concentration under standard assay conditions. Double reciprocal plots were constructed to determine the maximum binding amount of rat renin and prorenin to the immobilized recombinant receptors. Finally, molecular activities of receptor-bound renin and prorenin were calculated by dividing $V_{\max }$ values by their respective maximum binding amounts. For the soluble form of mature renin, molecular activity was estimated by dividing $V_{\max }$ value by the renin concentration used $(10 \mathrm{nM})$.

\section{Results}

Western blot analysis of the recombinant receptor. The recombinant rat renin/prorenin receptor from the cytoplasmic fraction of the insect cells migrated to the 40,000 region after Western blotting using anti-FLAG-M2 and anti-mouse IgG/HRP antibodies (Fig. 1a). The receptor preparation was allowed to immobilize in the wells of the 96-well plate, and these immobilized receptors were recognized by the antiFLAG (Fig. 1b) antibody.

Binding assay. In the case of rat renin and prorenin bound to the immobilized recombinant receptor, the absorbance was measured 0.631 and 0.621 , respectively at $450 \mathrm{~nm}$ under standard assay conditions. On the other hand, their respective blank values were 0.191 and 0.184 . The $K_{\mathrm{d}}$ values for the renin and prorenin binding to the rat renin/prorenin receptor were estimated at 8.3 and $20 \mathrm{nM}$, respectively (Fig. 2a and b). In each well, the amount of the immobilized recombinant receptor was calculated at $\sim 4.2$ pmole from the $K_{\mathrm{d}}$ value. The maximum binding amounts of renin and prorenin were 0.2 and 1.0 pmole, respectively (Fig. $2 \mathrm{a}$ and b).

Molecular activities of the soluble phase and receptor-bound renin and prorenin. The molecular activities of the receptorbound renin and prorenin were 10 and $1.1 \mathrm{~h}^{-1}$, respectively. The molecular activity of renin in the soluble phase was $1.25 \mathrm{~h}^{-1}$. 


\section{a. Renin bound to receptor}


b. Renin in soluble phase
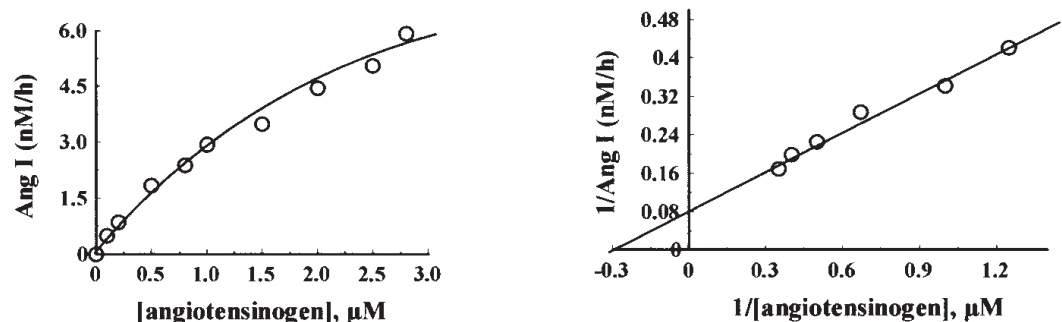

c. Prorenin bound to receptor
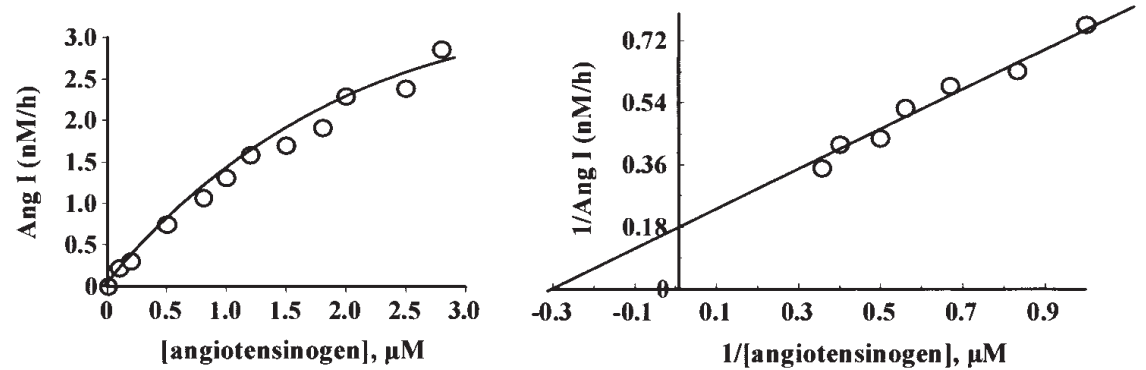

Figure 3. The Ang I generation rate by soluble phase and receptor-bound renin and prorenin. ( $\mathrm{a}$ and $\mathrm{b}$ ) Lineweaver-Burk plots of 1/Ang I/ h vs. $1 /$ angiotensinogen by renin bound to the receptors and in soluble phase $(10 \mathrm{nM})$, respectively. The $K_{\mathrm{m}}$ value was similar for both the cases estimated at $3.33 \mu \mathrm{M}$ while the $V_{\max }$ values determined from these plots were $10 \mathrm{nM} \cdot \mathrm{h}^{-1}$ and $12.5 \mathrm{nM} \cdot \mathrm{h}^{-1}$, respectively. (c) The Ang I generation rate by receptor-bound rat prorenin. The $K_{\mathrm{m}}$ and $V_{\max }$ values determined from the double reciprocal plot (1/Ang I generated/h vs. 1/angiotensinogen) were $3.33 \mu \mathrm{M}$ and $5.5 \mathrm{nM} \mathrm{h}^{-1}$, respectively. Rat renin and prorenin $(10 \mathrm{nM}, 200 \mu 1)$ were applied into each well containing immobilized receptors for each experiment.

The $K_{m}$ of receptor-bound rat renin and prorenin. Receptorbound renin and prorenin showed their enzymatic activities by cleaving sheep angiotensinogen. The $K_{\mathrm{m}}$ values of the receptorbound renin and prorenin using sheep angiotensinogen were similar at $3.33 \mu \mathrm{M}$ (Fig. 3a and c). The $K_{\mathrm{m}}$ value for the renin in soluble phase was also $3.33 \mu \mathrm{M}$ using the same substrate (Fig. 3b).

\section{Discussion}

We expressed rat renin/prorenin receptor by a baculovirus expression system to investigate biochemical properties of the receptor for in vitro binding to rat renin and prorenin. The receptor preparation obtained from the cytoplasmic fractions of insect cell transformants was confirmed by Western blotting using the antibody against the FLAG epitope. Its molecular weight was $40 \mathrm{kDa}$ (Fig. 1a) that was identical to that of human renin/prorenin receptor expressed in the COS-7 and human mesangial cells as reported by Nguyen et al (11).
The receptors immobilized in the wells of the 96-well plate were also recognized by the anti-FLAG-M2 antibody conjugated with Protein A-HRP (Fig. 1b). The binding of renin and prorenin to the receptor could be specifically observed by antibodies either against rat mature renin region or the $\mathrm{C}$-terminal region of rat prorenin prosegment.

Using sufficient amount of rat renin/prorenin receptor, we elucidated the binding properties of renin and prorenin to the common receptor to propose a possible binding mechanisms as shown in Fig. 4. We found that the $K_{\mathrm{d}}$ value for the binding of prorenin with the receptor was $8.3 \mathrm{nM}$ whereas this value for the renin was almost 2.5 times higher, $K_{\mathrm{d}}=20 \mathrm{nM}$ (Fig. $2 \mathrm{a}$ and $b$ ) indicating that prorenin prosegment plays a specific role in the prorenin-receptor binding. Suzuki et al (5) showed in vitro using region-specific antibodies that human prorenin has a 'handle' region in the prosegment sequence of prorenin molecule, and predicted that such a region played a key role in the binding with specific proteins $(5,23)$. The recombinant receptor has a 'high affinity region' as indicated by closed 


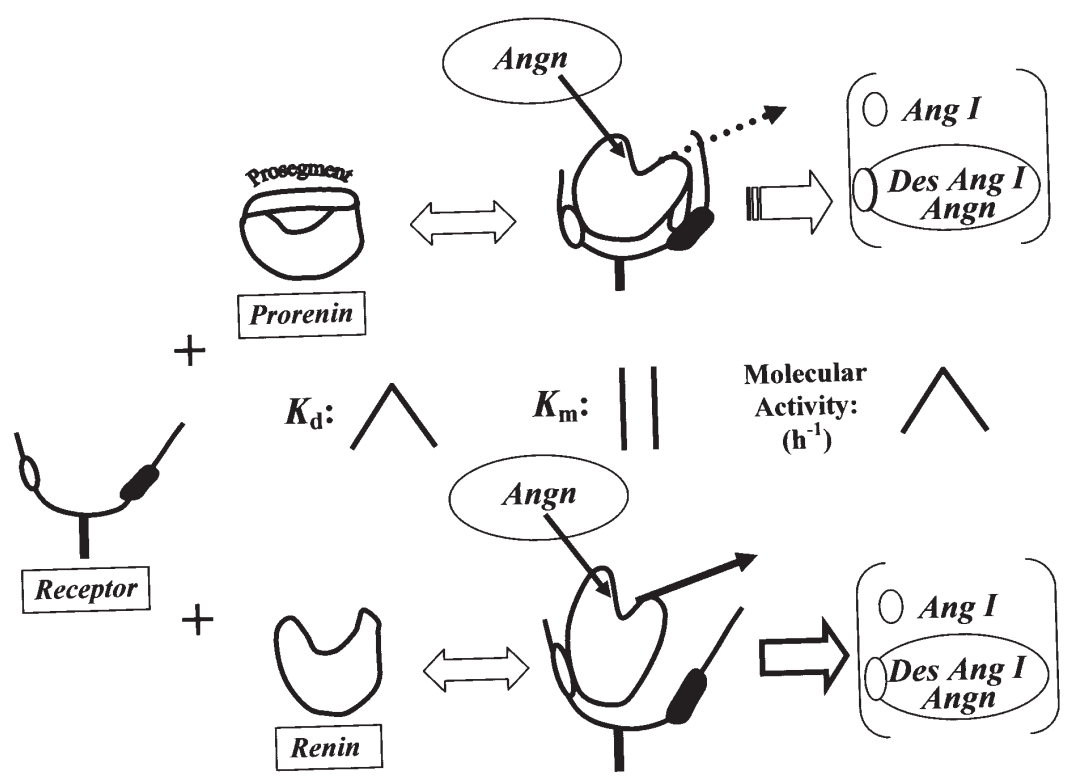

Figure 4. Possible binding mechanisms of renin and prorenin to the receptor. Each of the reactions was carried out at pH 6.5 to 7.5 . In the receptor, the associated regions specific to prorenin and common for renin as well as prorenin are indicated by the closed and open symbols, respectively.

symbols in Fig. 4, which could recognize specifically the 'handle' peptide of prosegment sequence of prorenin.

The same $K_{\mathrm{m}}$ value at $3.33 \mu \mathrm{M}$ for both the receptorbound renin and prorenin (Fig. $3 b$ and c) indicated the association of these two molecules with the receptor did not hinder making the complex of enzyme-substrate, prorenin/ renin-angiotensinogen, in the enzymatic level. The molecular activity of the receptor-bound renin was almost 10 times higher than that of prorenin. This is probably due to the change in the conformation of prorenin molecule by the association to the receptor, which ultimately delays the release of the products, angiotensin I and des-Ang Iangiotensinogen, as shown in Fig. 4.

We observed that rat prorenin was non-proteolytically activated by binding to the receptor within a short period (in minutes). This is the first finding that rat prorenin can be activated at $\mathrm{pH} 6.5$, because such activation has been reported only on observation under low $\mathrm{pH}$ and long time period (in days) $(15,16)$.

Rat renin bound to the receptor had 8 times higher molecular activity than that in the soluble phase, although the $K_{\mathrm{m}}$ was the same $3.3 \mu \mathrm{M}$, as shown in Fig. 3a and b. The turnover rate of the products from the complex of immobilized enzyme and substrate is higher than that of the free form of mature renin and substrate. This observation is similar to the data reported by Nguyen et al (11) that receptorbound human renin could generate Ang I from human angiotensinogen 4-5 times more efficiently compared to renin in solution. This is probably due to the cleft space of the renin molecule that was more altered under the complex with the receptor.

In this study, we have shown the physiological importance of renin/prorenin receptor and its probable role associated with the renin-angiotensin system, particularly with the local renin-angiotensin system on the cell membrane in vivo. Further study will elucidate other roles of the prosegment sequence of prorenin in this binding and the possibility of its association in signal transduction.

\section{References}

1. Fukamizu A, Nishi K, Cho T, Saitoh M, Nakayama K, Ohkubo H, Nakanishi S and Murakami K: Structure of the rat renin gene. J Mol Biol 201: 443-450, 1988.

2. Morris BJ: Molecular biology of renin I: Gene and protein structure, synthesis and processing. J Hypertens 10: 209-214, 1992.

3. Pitarresi TM, Rubattu S, Heinrikson R and Sealey JE: Reversible cryoactivation of recombinant human prorenin. J Biol Chem 267: 11753-11759, 1992.

4. Nguyen G, Burckle CA and Sraer JD: Renin/prorenin-receptor biochemistry and functional significance. Curr Hypertens Rep 2: 129-132, 2004.

5. Suzuki F, Hayakawa M, Nakagawa T, Uddin MN, Ebihara A, Iwasawa A, Ishida Y, Nakamura Y and Kazuo M: Human prorenin has 'Gate and Handle' regions for its non-proteolytic activation. J Biol Chem 278: 22217-22222, 2003.

6. van Kesteren CAM, Danser AHJ, Derkx, FHM, Dekkers DHW, Lamers JMJ, Saxena PR and Schalekamp MADH: Mannose 6phosphate receptor-mediated internalization and activation of prorenin by cardiac cells. Hypertension 30: 1389-1396, 1997.

7. Nakayama K, Hatsuzawa K, Kim WS, Hashiba K, Yoshino T, Hori $\mathrm{H}$ and Murakami K: The influence of glycosylation on the fate of renin expressed in Xenopus oocytes. Eur J Biochem 191: 281-285, 1990 .

8. Aeed PA, Guido DM, Mathews WR and Elhammer AP: Characterization of the oligosaccharide structures on recombinant human prorenin expressed in Chinese hamster ovary cells. Biochemistry 31: 6951-6961, 1992.

9. Andreasen PA, Egelund R and Petersen HH: The plasminogen activation system in tumor growth, invasion, and metastasis. Cell Mol Life Sci 57: 25-40, 2000.

10. Ellis V, Behrend $\mathrm{N}$ and Dano $\mathrm{K}$ : Plasminogen activation by receptor-bound urokinase. A kinetic study with both cell associated and isolated receptor. J Biol Chem 266: 12752-12758, 1991.

11. Nguyen G, Delarue F, Burcklé C, Bouzhir L, Giller T and Sraer J-D: Pivotal role of the renin/prorenin receptor in angiotensin II production and cellular responses to rennin. J Clin Invest 109: 1417-1427, 2002.

12. Nabi AHMN, Uddin MN, Nakagawa T, Sakata H, Iwata H, Ichihara A, Ishida Y, Inagami T and Suzuki F: Role of 'handle' region of prosegment part of prorenin in 'Receptor-associated Prorenin System'. J Hypertens 23 (Suppl 2): S259, 2005. 
13. Luckow VA and Summers MD: Trends in the development of baculovirus expression vectors. Biotechnology 6: 47-55, 1988.

14. Alior E and Betenbaugh MJ: Modifying secretion and posttranslational processing in insect cells. Curr Opin Biotechnol 10: 142-145, 1999.

15. Suzuki F, Takahashi A, Murakami K and Nakamura Y: Rat prorenin is activable at acidic pH. Genetic Hyper 218: 499-501, 1992.

16. Suzuki F, Nakagawa T, Kakidachi H, Murakami K, Inagami T and Nakamura Y: The dominant role of the prosegment of prorenin in determining the rate of activation by acid or trypsin: studies with molecular chimeras. Biochem Biophys Res Commun 267: 577-580, 2000.

17. Norling LL, Gomez RA and Inagami T: Characterization of a synthetic peptide antibody recognizing rat kidney renin and prorenin. Clin Nephrol 43: 232-236, 1995.

18. Tate CG, Whiteley E and Betenbaugh MJ: Molecular chaperones stimulate the functional expression of the cocaine-sensitive serotonin transporter. J Biol Chem 274: 17551-17558, 1999.

19. Yamauchi T, Suzuki F, Takahashi A, Ishizuka Y, Nakamura Y and Murakami K: Expression of rat renin in mammalian cells and its purification. Clin Exper Hypertens 14: 377-392, 1992.
20. Suzuki F, Yamashita S, Takahashi A, Ito M, Miyazaki S, Nagata Y and Nakamura Y: Highly sensitive microplate-ELISA for angiotensin I using 3,3',5,5'-tetramethylbenzidine. Clin Exp Hypertens A12: 83-95, 1990

21. Nagase M, Suzuki F, Sawai Y, Orihashi T, Inui Y, Nakagawa T and Nakamura Y: Purification and some properties of recombinant sheep angiotensinogen expressed in Chinese hamster ovary cells. Biomed Res 18: 439-443, 1997.

22. Murakami K, Suzuki F, Morita N, Ito H, Okamoto K, Hirose S and Inagami T: High molecular weight renin in stroke-prone spontaneously hypertensive rats. Biochim Biophys Acta 622: $115-122,1980$.

23. Ichihara A, Hayashi M, Kaneshiro Y, Suzuki F, Nakagawa T, Tada Y, Koura Y, Nishiyama A, Okada H, Uddin MN, Nabi AHMN, Ishida Y, Inagami T and Saruta T: Inhibition of diabetic nephropathy by a decoy peptide corresponding to the 'handle' region for nonproteolytic activation of prorenin. J Clin Invest 114: 1128-1135, 2004. 